\section{Achieving evidence for the management of arthralgia at risk for RA. Response to: 'The cost of arthralgia 'pretreatment' to prevent rheumatoid arthritis' by Rothschild}

We read the letter from Rothschild with interest. ${ }^{1}$ We agree that we need more data and better evidence on: (1) how to determine the risk of patients with arthralgia progressing to 'true RA' and on (2) whether or not Disease Modifying AntiRheumatic Drug (DMARD) treatment is better than placebo in this phase. Both points were discussed in our Viewpoint. ${ }^{2}$ Cost-benefit analyses can only be performed afterwards.

Rothschild seems to agree with us not to condone treating patients presenting with arthralgia with DMARDs, pending further evidence. Still, there are different opinions in the field. This is illustrated by a recent study from the UK, in which rheumatologists were asked about their management in clinical practice of arthralgia patients with positive anti-cyclic citrullinated peptide antibodies antibodies and signs of synovitis on power Doppler in at least one joint, but in the absence of clinically apparent arthritis. Seventy-one per cent of consultants said to start DMARD treatment, $16 \%$ would treat with glucocorticoids only, $8 \%$ considered inclusion in a clinical trial and only 3\% replied to wait and see without immediate initiation of DMARD treatment. ${ }^{3}$

We believe it may be harmful if the rheumatic field gets too comfortable with initiating DMARD treatment already in arthralgia patients with a certain risk of developing true rheumatoid arthritis (RA) without solid proof. Such a behaviour hampers the course of observational studies to properly determine the risk of RA in individual patients. Hindering the natural course of patients in observational studies with DMARD treatment means that we will never be able to know which patients are being overtreated. Importantly, the regular use of DMARDs in this setting may also hinder the inclusion of arthralgia patients in ongoing and future placebo-controlled trials, as this will then be considered increasingly counterintuitive or unethical because physicians in daily clinical practice may increasingly consider DMARD treatment standard of therapy.
Annette van der Helm-van Mil $\odot{ }^{1,2}$ Robert BM Landewée e $^{3,4}$

${ }^{1}$ Rheumatology, Leiden University Medical Center, Leiden, The Netherlands

${ }^{2}$ Rheumatology, Erasmus Medical Center, Rotterdam, The Netherlands

${ }^{3}$ Amsterdam Rheumatology Center, AMC, Amsterdam, The Netherlands

${ }^{4}$ Rheumatology, Zuyderland MC, Heerlen, The Netherlands

Correspondence to Professor Annette van der Helm-van Mil, Rheumatology, Leiden University Medical Center, 2333 ZA Leiden, The Netherlands; A.H.M.van_der_Helm@lumc.nl

Handling editor Josef S Smolen

Funding The authors have not declared a specific grant for this research from any funding agency in the public, commercial or not-for-profit sectors.

Competing interests None declared.

Patient consent for publication Not required.

Provenance and peer review Commissioned; internally peer reviewed.

(C) Author(s) (or their employer(s)) 2020. No commercial re-use. See rights and permissions. Published by BMJ.

D) Check for updates

To cite van der Helm-van Mil A, Landewé RBM. Ann Rheum Dis Epub ahead of print: [please include Day Month Year]. doi:10.1136/annrheumdis-2020-216984

Received 15 January 2020

Accepted 15 January 2020

\section{Linked}

http://dx.doi.org/10.1136/annrheumdis-2020-216981

Ann Rheum Dis 2020;0:1. doi:10.1136/annrheumdis-2020-216984

\section{ORCID iD}

Annette van der Helm-van Mil http://orcid.org/0000-0001-8572-1437

\section{REFERENCES}

1 Rothschild B. The cost of arthralgia "pretreatment" to prevent rheumatoid arthritis. Ann Rheum Dis.

2 van der Helm-van Mil A, Landewé RBM. The earlier, the better or the worse? towards accurate management of patients with arthralgia at risk for RA. Ann Rheum Dis 2020:pii: annrheumdis-2019-216716.

3 Mankia K, Briggs C, Emery P. How are rheumatologists managing Anticyclic citrullinated peptide Antibodies-positive patients who do not have arthritis? I Rheumatol 2019:jrheum. 190211. 